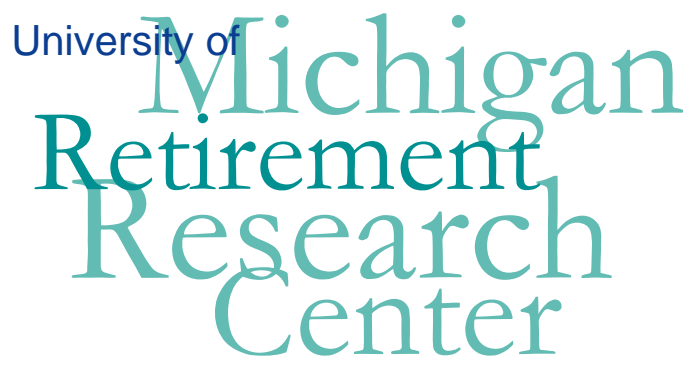

Working Paper

WP 2004-075

\title{
Economic Adjustment of Recent Retirees to Adverse Wealth Shocks
}

Gabor Kezdi and Purvi Sevak

\begin{tabular}{|l|l|}
\hline $\mathrm{M}$ & $\mathrm{R}$ \\
\hline $\mathrm{R}$ & $\mathrm{C}$ \\
\hline
\end{tabular}$\quad$ Project \#: UM03-S1 


\title{
"Economic Adjustment of Recent Retirees to Adverse Wealth Shocks"
}

\author{
Gabor Kezdi \\ Central European University \\ Purvi Sevak \\ Hunter College
}

\begin{abstract}
April 2004
Michigan Retirement Research Center

University of Michigan

P.O. Box 1248

Ann Arbor, MI 48104
\end{abstract}

\section{Acknowledgements}

This work was supported by a grant from the Social Security Administration through the Michigan Retirement Research Center (Grant \# 10-P-98358-5). The opinions and conclusions are solely those of the authors and should not be considered as representing the opinions or policy of the Social Security Administration or any agency of the Federal Government.

\section{Regents of the University of Michigan}

David A. Brandon, Ann Arbor; Laurence B. Deitch, Bingham Farms; Olivia P. Maynard, Goodrich; Rebecca McGowan, Ann Arbor; Andrea Fischer Newman, Ann Arbor; Andrew C. Richner, Grosse Pointe Park; S. Martin Taylor, Gross Pointe Farms; Katherine E. White, Ann Arbor; Mary Sue Coleman, ex officio 


\title{
Economic Adjustment of Recent Retirees to Adverse Wealth Shocks
}

\author{
Gabor Kezdi \\ Purvi Sevak
}

\begin{abstract}
Since the mid-nineties, the stock market has had an unprecedented impact on the wealth of current and future retirees. Using data from the Current Population Survey and the Health and Retirement Study, this report estimates consumption and labor supply responses of individuals in their 50s and 60s to the recent stock market downturn. We estimate an elasticity of consumption with respect to wealth changes ranging from five to seven percent. This implies that households respond to a decline in wealth by reducing their consumption by 5 to 7 percent of the wealth decline. For example, if a household's wealth declined by $\$ 100,000$, this estimate suggests they would reduce their annual consumption by $\$ 5,000$ to $\$ 7,000$. Among retirees, we do not observe any re-entry into the labor force in response to wealth losses due to stock market declines. This suggests that retirement is more or less an absorbing state, for either supply or demand reasons: once an individual retires, it is very difficult to become employed once again.
\end{abstract}




\section{Introduction}

Since the mid-nineties, the stock market has had an unprecedented impact on the wealth of current and future retirees. Through the spread of defined contribution pension plans, an increasing number of retirement age individuals have substantial proportions of their retirement wealth invested in the stock market. The strong performance of the market from 1994 to 2000 substantially increased the retirement wealth of those invested in stocks. The sharp decline of stock values in 2000 and the following bear market had the opposite effect on retirement wealth. This study quantifies the magnitude of the wealth loss and estimates some behavioral responses of retirement age households to these losses. These responses include delayed retirement, reentry to the labor force, and reducing consumption.

This period of study should be useful in exploring fundamental economic issues that have proven difficult to study empirically. Because the fluctuations in asset values were so large and at least to some degree unexpected, with high quality data one can isolate variation in wealth off of which to identify behavioral responses. Understanding the impact of market fluctuations on retirement wealth, and the responses of individuals to these impacts, is of fundamental importance to retirement policy. This is particularly true as individual accounts are considered for Social Security.

We estimate an elasticity of consumption with respect to wealth changes ranging from five to seven percent. Our estimated labor supply responses are less consistent. The outline of this report is the following. The next section presents the background and significance of the research questions. Section III introduces a simple theoretical model 
to frame the subsequent empirical investigation. Section IV reviews the main findings of previous studies. Section V presents our results on labor supply responses to recent stock market declines, and section VI presents our estimates of consumption responses. Section VII concludes.

\section{Background and Significance}

The method of financing ones retirement is fundamentally different today than it was 20 years ago. Workers now bear more of the responsibility and accompanying risk in retirement wealth accumulation than they did in the past. The major factor behind this is the shift from defined benefit (DB) to defined contribution pension (DC) plans. ${ }^{1}$ Whereas employers bear the financial risk in DB plans, which pay a fixed annuity in retirement, workers bear the risk in a DC plan. The composition of private household savings has also changed in a way that increases risk. There has been a significant increase in stock ownership during the 1990’s from about one-third of households investing in stocks in 1989 to one-half (Poterba, 2001). Thus, between 1989 and 1999, the share of household net worth invested in equity through stocks or mutual funds more than doubled, from 12 to 29 percent. $^{2}$ This was partly due to the long and spectacular growth of stock values in the nineties. This growth in stock values is illustrated in Figure 1, which plots the year-end values of the Standard and Poor's 500 Index. The dramatic increases from 1994 to 2000 translated into substantial increases in retirement resources particularly for those with DC pension plans. However, it also translated into a greater burden of risk.

\footnotetext{
${ }^{1}$ Between 1975 and 1997, the percent of pension participants covered primarily by a DC plan increased from 30 percent to 68 percent (Munnell et al., 2002).

${ }^{2}$ Federal Reserve Board's Flow of Funds (Series Z.1 Table B.100)
} 
Table 1 describes exposure to the stock market, through direct stock holdings, mutual funds, and IRAs, among retired households in the HRS in $2000 .^{3}$ The median retired household under age 75 had roughly 10 percent of their non-pension wealth invested in stocks. However, roughly 25 percent of retired households have over 40 percent of their wealth invested in stocks. Thus, it seems a non-trivial number of retired households may have lost much of their wealth since 2000. As Table 2 shows, among direct stockholders (those who held stocks in non-retirement accounts), the percent of wealth invested in stocks (through direct stock holdings, mutual funds, and IRAs) is even higher. The median share of financial wealth invested in stocks is close to 40 percent. Given this exposure to stock market risk, many of the households who saw their wealth grow in the nineties saw their gains disappear in the past two years. The burst of the dot.com bubble and the following bear market significantly decreased retirement wealth. This is particularly true for individuals who did not diligently reallocate their portfolios. As Figure 1 illustrates for the S\&P 500, between 2000 and 2002 stock values fell dramatically. If we assume that the average retired households in our sample had a portfolio that performed as the S\&P 500, and that it did not reallocate their portfolio, we estimate that between the end of 2000 and the end of 2002, their stock holdings stood to decline in value by one-third. The hit that any particular household took depends on their exposure to the stock market. Figure 2 displays the distribution of projected losses among households that held stocks outside of retirement accounts. The median loss was about 15 percent of one’s non-pension financial wealth and 25 percent of households lost at least 20 percent.

\footnotetext{
${ }^{3}$ A household is defined as retired if at least one member has retired.
} 
Although the decline in stock prices affects all individuals who are invested in stocks, it is particularly important for individuals who have already retired, because retirement is costly to reverse. Households that retired in the late nineties did so with some assumption about the standard of living they could maintain conditional on that retirement age. Those with a substantial share of resources invested in stocks now face a dilemma: reduce consumption or increase labor supply. To maintain their consumption without increasing labor supply, they must continue to withdraw from their portfolios. However, because its value has declined sharply, this strategy means they will run out of resources earlier, even given reasonable upswings in the market in the future. In this paper, we separately estimate consumption responses and labor supply responses for individuals in or close to retirement.

\section{Theoretical Motivation}

We can relate measured changes in consumption and labor supply to behavioral parameters by specifying a simple model of labor supply and consumption under uncertainty. At each time period $t$, the decision-maker specifies a path from $t$ to $T$ (the end of life) of future consumption $(C)$, labor supply in hours $(H)$, wealth to bequeath $\left(A_{T+1}\right)$ and portfolio composition $\left(s_{1}\right.$ through $\left.s_{K}\right)$ by maximizing

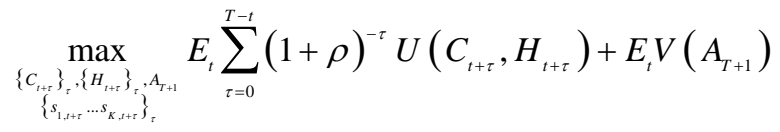

subject to the intertemporal budget constraint

$$
\Delta A_{t+\tau}=A_{t+\tau+1}-A_{t+\tau}=\left(r_{t+\tau}+Z_{t+\tau}\right) A_{t+\tau}+B_{t+\tau}+W_{t+\tau} H_{t+\tau}-C_{t+\tau}
$$

and the portfolio shares defined as 


$$
S_{k t}=\frac{A_{k t}}{A_{t}} \text {, so that }\left(r_{t}+Z_{t}\right)=\sum_{k=1}^{K}\left(r_{k}+Z_{k t}\right) s_{k t} \text {. }
$$

$U$ is the instantaneous utility function, while $V$ is the utility of leaving bequest. $A$ is the total value of assets, $A_{k}$ is value of the $k^{\prime}$ th asset, and $s_{k}$ is the share of asset $k . B$ is unearned income (such as Social Security benefits or defined benefits pensions), $W$ is wages (assumed to be known with certainty), and $H$ is total hours worked.

$(r+Z)$ is the rate of return on total assets, where $r$ is the expected return on the assets (assumed to be known), and $Z$ is a mean-zero shock. We model $r$ and $Z$ separately because we want to focus on changes in wealth that are both unexpected and permanent. $r$ may change with time because the individual's portfolio could change, which would change the expected returns on total assets. At the same time, this change in expected returns is conceptually different from unexpected shocks to the value of assets. The latter are captured by $Z_{k}$ and their weighted average, $Z$. We make the crucial assumption that asset prices follow a random walk and therefore the $Z_{k t}$ are i.i.d. As a result, the value of a fixed portfolio also follows a random walk.

The solution to the problem is an optimal path of consumption, labor supply, and portfolio shares, and an optimal amount of assets planned for bequests. Our empirical analysis is motivated by the desire to estimate the following elasticities:

$$
\frac{d \ln C^{*}}{d \ln Z} \text {, and } \frac{d \ln H^{*}}{d \ln Z} \text {. }
$$

These approximate short-run total income effects on consumption and labor supply, and effects on planned bequests. ${ }^{4} \quad$ Because we cannot observe $\mathrm{Z}$, we estimate

$$
\frac{d \ln C^{*}}{d \ln A} \text {, and } \frac{d \ln H^{*}}{d \ln A} .
$$


These derivatives estimate effects after possible changes in a household's portfolio, but we will not address the problem of asset allocation in our study. The estimated elasticities are informative about whether individuals reduce their consumption or change their labor supply.

\section{Empirical Motivation: Previous Empirical Literature}

A substantial literature exists on the effects of wealth shocks on consumption. A recent paper using the HRS finds that displaced workers who are close to retirement age reduce their annual food consumption by 15 percent following displacement (Stephens, 2002). Using the PSID, Mankiw and Zeldes (1990) find that the consumption of stockholders shows more volatility than that of non-stockholders and that it covaries with stock market returns. The magnitude of the response suggested by standard theoretical models, measured as the marginal propensity to consume (mpc) out of wealth, is 0.03 . That is, individuals increase their annual consumption for the remaining years of life by 3 cents for every additional dollar of wealth. More detailed models suggest a much higher mpc. ${ }^{5}$ A substantial literature tries to empirically estimate this wealth effect. Using the Survey of Consumer Finances, Maki and Palumbo (2001) estimate an mpc out of wealth of 3 to 5 cents-to-the-dollar. Using detailed consumption data from the Consumer Expenditure Survey, Dynan and Maki (2001) estimate larger wealth effects - an mpc of 5 cents to 15 cents for households with moderate security holdings.

\footnotetext{
${ }^{4}$ In this report, we measure discrete rather than continuous changes in hours, that is we estimate the responsiveness of participation.

${ }^{5}$ See for example, Kimball (1990), Carroll (1997) and Deaton (1991).
} 
A number of papers explore the effects of different sources of wealth and the overall economic climate on the retirement decision. Using the period from 1992 to 1998, Sevak (2003) finds that individuals retire earlier in response to unexpected capital gains. If individuals respond symmetrically to losses and gains, her findings suggest that individuals should delay retirement in response to unexpected losses. Indeed, Anderson et al. (1986) find that the 1970s recession tended to delay retirement. However, Krueger and Pischke’s (1992) study of the “notch babies” who experienced a large, unanticipated reduction in Social Security wealth found no retirement response to these reductions in Social Security benefits. In addition, a recent paper by Chan and Stevens (2002) finds that job loss experienced close to retirement age - a shock that is associated with a loss of wealth, is actually associated with earlier retirement. But the observed response is a combination of the income effect of reduced wealth and the substitution effect due to reduced wages, and their evidence suggests that the substitution effect dominates.

These studies have focused on retirement responses to wealth shocks, but to date there has not yet been an examination of labor supply responses of those already retired. Eschtruth and Gemus (2002) show that between 2001 and 2002, labor force participation for older workers (ages 55-64) increased. They also show that the observed increase is unprecedented in earlier recessions. This is suggestive evidence that stock market declines may have caused delayed retirement but their analysis of aggregate participation rates cannot provide evidence for this claim. The substantial literature documenting consumption declines at retirement (Hammermesh (1984), Hausman and Paquette (1987), Banks et al. (1998)) suggests that retirees may adjust consumption rather than labor supply, in response to adverse shocks. Haider and Loughran's (2001) finding that the elderly labor supply is concentrated among the wealthiest, healthiest, and most educated 
elderly, also suggests that the elderly do not return to (or remain in) the labor market in response to financial pressure. This may be due to the fact that it is costly to reenter the labor force after retirement, because of depreciation of human capital, deteriorating health, and age discrimination. The lack of empirical research on this timely topic may be due to the fact that until recently, wealth of retired individuals was subject to little fluctuation, aside from that due to inflation, thus providing the researcher with little variation off of which to identify effects.

A possible adjustment mechanism to adverse shocks is a change in bequest plans. Hurd and Smith (2002) find that the elderly change their bequest intent when they experience positive wealth shocks. They estimate a corresponding average elasticity of about 1.3. This suggests that bequests may play a buffer role in that households with wealth to bequeath will have to adjust their consumption less as a response to the negative wealth shock, if they are willing to reduce their planned bequests.

\section{Consumption Responses}

We first examine consumption responses to wealth losses using the Health and Retirement Study (HRS). HRS contains detailed questions about wealth, savings, consumption, and labor supply on individuals born in 1947 and earlier (ages 51 and older in 1998). Among other items, respondents are asked about home values, mortgages, direct investment in stocks or mutual funds, and wealth in their IRA and DC pension accounts. $^{6}$ We use the 1998, 2000, and 2002 survey waves.

Figures 3 and 4 show how the levels of these assets changed among respondents of comparable ages over the period. The value of stocks and IRAs increased from 1998

\footnotetext{
${ }^{6}$ We assume that one-half of IRA or DC pension balances are invested in equity and one-half in bonds.
} 
and 2000 and decreased between 2000 and 2002, Table 3 provides more details by showing asset values by age cohort.

Our basic specification is a regression of $\Delta \log$ Food Consumption on $\Delta \log$ Assets, where $\Delta$ is the change between 2000 and 2002. The coefficient on $\Delta \log$ Assets is our estimate of the wealth elasticity of consumption. Assets are the sum of reported values of stocks, bonds, IRA balances, DC pension plan balances, housing, businesses, and bank accounts. The primary measure of consumption in most waves of HRS is food consumption (food delivered to the home, other food consumed at home, and food consumed away from home). By relying only on food, we obviously miss a large part of total consumption, which is problematic if food is nonseparable from other types of consumption. However, food consumption has been a standard proxy for total consumption effects in panel data (see for example Stephens (2002), Hall and Mishkin (1982), Altonji and Siow (1987), Zeldes (1989)) and may be better measured than other components of consumption. Food is also nondurable, which makes it suitable to estimate theoretical consumption elasticities.

In Table 4 we present results for three specifications that control for different covariates. Standard errors are robust to heteroskedasticity. ${ }^{7}$ The first column of Table 8 shows that without controlling for other factors, the estimated elasticity of food consumption with respect to wealth is about four percent. In the second column, we control for lagged changes in assets and consumption, to attempt to control for unmeasured trends in consumption and measurement error. It should be noted that lagged consumption is an awkward measure here: in 1998, it is total (as opposed to food)

\footnotetext{
${ }^{7}$ In addition, we cluster at the original 1992 household level to account for the fact that some separate households in 1998 that are separate in 1998 but were not in 1992 (households that divorce or separate) may have experienced some common unmeasured changes.
} 
consumption that enters the 1998 to 2000 difference. While the sign of the lagged consumption change is consistent with large iid measurement error in reported consumption, (and therefore a negative correlation of measurement error in changes) the estimated wealth elasticity of consumption does not change very much. Lastly, in the third column, we control for a variety of factors that may affect consumption changes, including age, education, health, medical expenditure, one's life expectancy, and beliefs about the stock market. Mean values for these covariates are in the last column. When we control for these factors, the estimated elasticity increases to five percent.

Because retirement is costly to reverse, retired households may be less likely to adjust their labor supply and more likely to adjust their consumption in response to wealth losses. ${ }^{8}$ To test whether retired households are more likely to adjust their consumption, we separately estimate consumption regressions among households that reported being retired in 1998. Results in Table 5 suggest that the retired households have a higher consumption response. The elasticity of food consumption with respect to wealth is 7.3 percent among retired households. This is two percentage points or about a third higher than the estimated elasticity among all households.

The motivation for focusing on 2000 to 2002 changes was the fact that a large share of asset changes in this period were due to the stock market crash and were therefore exogenous to household behavior. We also estimated the above regressions among the subset of couples that owned risky assets (stocks, IRA and DC accounts) in 1998, those that experienced a negative wealth shock, and the union of the two. We also estimated IV regressions where we instrumented for log change in total wealth using the

\footnotetext{
${ }^{8}$ We also find some evidence of this in the next section where we examine labor supply responses.
} 
log change in risky assets. Estimated elasticities were all very similar to the baseline ones in Tables 4 and 5, increasing our confidence in the robustness of our results. ${ }^{9}$

To test whether there is heterogeneity in the consumption elasticity across households, we run a nonparametric version of the regressions described above. The estimated effects are quite symmetric across households and are illustrated graphically in Figure 5. Figure 6, however, shows that the same is not true for households that held risky assets in 1998. The reason for these discrepancies is subject to further research. The magnitude of the effect is also quite small. Quantifying the effect and relating it to household characteristics (above all health and life expectancy) is also on our research agenda.

\section{Labor Supply Responses}

\section{VI.I. Labor Force Transitions}

We next look at labor supply responses to the wealth shocks. Given the findings in Eschtruth and Gemus (2002) that labor force participation for older workers increased between 2001 and 2002, we try and decompose the share of this increase that is due to transitions into and transitions out of the labor force. Thus, in this section, we examine labor force transitions, with a focus on transitions between work and retirement.

In order to focus on transitions, we used matched monthly CPS data from multiple sets of two consecutive years. We matched new interviews (" $\mathrm{t}_{0}$ ") to interviews one year later ("t $\left.t_{1}\right) .{ }^{10}$ Figure 7 graphs participation rates over time (at $\left.t_{1}\right)$ of a "pre-retirement cohort” of individuals ages 50-54 years old and a “retirement age cohort” of individuals

\footnotetext{
${ }^{9}$ We do not present the results of these but they are available from the authors upon request.

${ }^{10}$ We merge individual records across March CPS interviews using household and person identifiers, along with sex, age, and race of the respondent.
} 
ages 55-64 years old. The graph re-establishes the finding in the last section and that of Eschtruth and Gemus (2002): participation of pre-retirement cohorts did not change much during the recession - if anything, it decreased a bit. At the same time, labor force participation of people around retirement increased substantially, from around 0.60 in 2000 to almost 0.64 by 2003.

The aggregate participation rate of a group decreases naturally as they age. The observed increase in the aggregate participation rate of 55-64 year olds was therefore partly a result of a smaller decrease in aggregate participation. Figure 8 shows year-toyear changes of aggregate participation of individuals that are observed at both $t_{0}$ and $t_{0}$. In essence it shows how much the aggregate participation rate of people of the same birth-cohort decreased from one year before, and plots those rates against calendar time at $t_{1}$. The year-to-year drop in the aggregate participation rate of these people decreased from more than 5 percent to a little over 4 percent.

We can decompose the aggregate year-to-year change in aggregate labor force participation rate into two components: changes in the transition rate from participation to non-participation and changes in the transition rate from non-participation to participation. Let $\mathrm{P}$ denote the number of individuals who are in the labor force, which is made up of: the working (W) and the unemployed (U), so that $\mathrm{P}=\mathrm{W}+\mathrm{U}$. Similarly, let $\mathrm{O}$ denote individuals who are out of the labor force: the retired (R) and those that are inactive for other reasons (I), so that: $\mathrm{O}=\mathrm{R}+\mathrm{I}$. Let lowercase equivalents denote the appropriate rates, and $\mathrm{N}$ denote the population. Then

(6) $p_{t}=\frac{P_{t}}{N_{t}}=\frac{W_{t}+U_{t}}{N_{t}}=w_{t}+u_{t}$

(7) $p_{t}=\frac{P_{t}}{N_{t}}=1-\frac{O_{t}}{N_{t}}=1-\frac{R_{t}+I_{t}}{N_{t}}=1-r_{t}-i_{t}$ 
which state that the participation rate can be defined as the sum of the working and unemployment rates, or as 1 minus the retirement and other inactive rate; and

(8) $\Delta p_{t} \equiv p_{t}-p_{t-1}=\frac{P_{t}}{N_{t}}-\frac{P_{t-1}}{N_{t-1}}=\frac{P_{t}-P_{t-1}}{N_{t}}$, because $N_{t}=N_{t-1}$ (matched sample).

We can decompose the set of individuals in and out of the labor force into the subset of individuals continuing in or transitioning into that status between $t-1$ and $t$. The matrix below describes these groups.

\begin{tabular}{|l|c|c|c|}
\hline & $\begin{array}{c}\text { In the labor } \\
\text { force (t) }\end{array}$ & $\begin{array}{c}\text { Out of the labor } \\
\text { force (t) }\end{array}$ & SUM $_{\mathbf{t}-\mathbf{1}}$ \\
\hline In the labor force (t-1) & $\mathrm{pp}_{\mathrm{t}}$ & $\mathrm{po}_{\mathrm{t}}$ & $\mathrm{p}_{\mathrm{t}-1}$ \\
Out of the labor force (t-1) & $\mathrm{op}_{\mathrm{t}}$ & $0 \mathrm{o}_{\mathrm{t}}$ & $\mathrm{O}_{\mathrm{t}-1}$ \\
\hline SUM $_{\mathbf{t}}$ & $\mathrm{p}_{\mathrm{t}}$ & $\mathrm{o}_{\mathrm{t}}$ & 1 \\
\hline
\end{tabular}

Then we have that

(9) $\Delta p_{t}=p_{t}-p_{t-1}=\left(p p_{t}+o p_{t}\right)-\left(p p_{t}+p o_{t}\right)=o p_{t}-p o_{t}$.

That is, a year-to-year change in participation rates is the sum of transition from nonparticipation to participation and transition of the opposite direction. An increase in the change in labor force participation rates is therefore either because of a higher transition from non-participation to participation or a lower opposite transition.

We have divided the January 1999 to June 2003 period into three periods: January 1999 to May 2000, June 2000 to December 2001, and January 2002 to June 2003 (all referring to time t observations, for which t-1 observations are available). Table 6 shows the results of the above decomposition of $\Delta p$, for the three periods. From it, we can conclude that the increased participation in the last period is almost entirely due to a smaller transition from participation to non-participation. While the decrease in exits 
from the labor force is not surprising, it is remarkable however, how little the rate of reentry into the labor force has increased.

To examine the importance of possible changes in unemployment rates, we can further decompose changes in participation rates into more detailed components:

$$
\text { (10) } \begin{aligned}
\Delta p_{t}=p_{t}-p_{t-1}=w w_{t}+u w_{t}+r w_{t}+i w_{t}+w u_{t}+u u_{t}+r u_{t}+i u_{t} \\
-w w_{t}-w u_{t}-w r_{t}-w i_{t}-u w_{t}-u u_{t}-u r_{t}-u i_{t} \\
=r w_{t}+i w_{t}+r u_{t}+i u_{t}-w r_{t}-w i_{t}-u r_{t}-u i_{t}
\end{aligned}
$$

\begin{tabular}{|c|c|c|c|c|c|}
\hline & Working $_{t}$ & Unemployed $_{\mathrm{t}}$ & Retired $_{\mathrm{t}}$ & Other inactive $_{t}$ & SUM $_{\mathrm{t}-1}$ \\
\hline Working $_{t-1}$ & $\mathrm{wW}_{\mathrm{t}}$ & $\mathrm{wu}_{\mathrm{t}}$ & $\mathrm{wr}_{\mathrm{t}}$ & $w i_{t}$ & $\mathrm{~W}_{\mathrm{t}-1}$ \\
\hline Unemployed $_{\mathrm{t}-1}$ & $\mathrm{uw}_{\mathrm{t}}$ & $\mathrm{uu}_{\mathrm{t}}$ & $\mathrm{ur}_{\mathrm{t}}$ & $u i_{t}$ & $\mathrm{u}_{\mathrm{t}-1}$ \\
\hline Retired $_{\mathrm{t}-1}$ & $\mathrm{rW}_{\mathrm{t}}$ & $\mathrm{ru}_{\mathrm{t}}$ & $\mathrm{rr}_{\mathrm{t}}$ & $\mathrm{ri}_{\mathrm{t}}$ & $\mathrm{r}_{\mathrm{t}-1}$ \\
\hline Other Inactive $_{\mathrm{t}-1}$ & $\mathrm{iw}_{\mathrm{t}}$ & $\mathrm{iu}_{\mathrm{t}}$ & $i r_{t}$ & $\mathrm{ii}_{\mathrm{t}}$ & $\mathrm{i}_{\mathrm{t}-1}$ \\
\hline SUM & $\mathrm{W}_{\mathrm{t}}$ & $\mathrm{u}_{\mathrm{t}}$ & $\mathrm{r}_{\mathrm{t}}$ & $i_{t}$ & 1 \\
\hline
\end{tabular}

where the transitions are defined according to the following table:

The results of the decomposition for the three time-periods are shown in Table 7. They show that the decrease in participation declines is almost completely explained by the decrease in direct transitions from work to retirement. The behavior of the unemployed and others who are not employed do not seem to change very much, in either way. This may be because they were not affected by the stock market crash: the unemployed and those not in the labor force but not retired may not have significant Defined Contribution pension plans that can lose value with fluctuations of the stock market.

The results indicate that labor supply responses are very asymmetric. Working people seem to react to adverse wealth shocks by delaying retirement. At the same time, those already retired do not increase their labor supply. This asymmetry may indicate two things: either the retired are less willing to go back to work than delay retirement if they 
are still working, or employers are less willing to hire recent retirees than allow people to stay on their job and delay retirement. The source of this asymmetry calls for further research.

\section{2. Heterogeneity in labor supply responses: Cross-Sectional Analysis}

If delayed retirement is really due to decreased wealth (including pension wealth), we should see heterogeneity in these responses. Because many individuals do not own stocks, their labor supply should not show wealth effects in this period. In testing for wealth effects, it could be useful to compare trends in labor supply among stock owners and others. Unfortunately, the CPS has no information on asset holdings or wealth. They do report income from a variety of sources, including dividend income. Although some stock owning households may not receive any dividend income, because of data limitations, we treat households that receive dividend income as stock owners and other households as non-stock owners. We estimate logit equations of whether an individual was out of the labor force of the form:

$$
N I L F_{i t}=f\left(\beta_{1} S_{i t}+\sum_{t=1988}^{2002} \gamma_{t} Y_{t}+\sum_{t=1988}^{2002} \delta_{t} S_{i t} Y_{t}+X_{i t} \lambda+v_{i t}\right)
$$

$S$ equals one if the household holds stock (as proxied by dividend income) and $\beta_{1}$ captures any time invariant relationship between stock ownership and labor supply. $Y$ indexes the year and thus $\gamma$ captures year fixed effects. $X$ is a vector of observable characteristics that may be correlated with retirement behavior, including age, marital status, presence of children, and unearned income. The coefficients on the interaction of the year dummy variables and the dummy variable for stockholders $\delta$, identify any additional changes in labor force participation from year to year observed for 
stockholders. If retirement age individuals return to the labor force (or delay retirement) in response to stock market losses, we would expect these coefficients to be negative for the years 2001 and 2002.

Table 8 has estimates for equation 11, estimated separately for men and women. Marginal effects are in the first column and are followed by estimated coefficients and standard errors. $^{11}$ Not surprisingly, age has the strongest effect in explaining whether or not someone is in the labor force. Being married and having children under the age of 18 decreases the probability a man is out of the labor force but increases the probability that a woman is out of the labor force. Greater unearned income increases the probability that both men and women are out of the labor force, consistent with an income effect. On the other hand, being a stockowner reduces the probability that one is not in the labor force. The coefficient on the year variables show a trend towards increased labor supply for both men and women over time.

The coefficients on the interaction term of being a stockowner and being observed in 2001 or 2002 are negative and statistically significant for both men and women, supporting the hypothesis that the downturn in the stock market increased labor supply. Once controlling for the relationship between owning stock and labor supply, and year fixed effects, stockowners in 2001 were about four to six percentage points less likely to be out of the labor force than those who did not own stocks. Given that the percent of men and women out of the labor force was 42 percent and 59 percent, respectively, the coefficient estimates translate into an effect of 10 percent. This effect increases to 15 percent for men in 2002.

\footnotetext{
${ }^{11}$ The reported marginal effect is calculated as the average marginal effect across all the observations.
} 
However, we are hesitant to interpret this as a causal effect. The differential time trend for stockowners is present well before the downturn in the stock market and the sign on the interaction terms are negative even during the bull market. Thus, the estimated negative wealth effect could be a continuation of a time trend that began earlier. We explore this issue further in the next section, using panel data from the Health and Retirement Study.

\section{3. Heterogeneity in labor supply responses: Panel Analysis}

After the simple cross-sectional analysis, we turn to panel data with better asset information. We look at labor force transitions similar to section VI.1 but try to see if changes in transition rates were different for those who owned risky assets in 1998 from those who did not. In essence, we carry out a difference-in-differences exercise on labor force transitions. We focus on transitions between work and retirement because the results in section VI.1 clearly showed that it is this margin on which labor force participation of retirement aged individuals changed during the 2001-2002 recession.

We use data from the 1998-2002 waves of the Health and Retirement Study. The sample is made up of individuals of the original HRS cohort who are between 52 and 72 years old, who were interviewed in all 3 waves and whose family status did not change during the 1998-2002 period. Risky assets were defined as stocks and mutual funds, IRA and DC accounts.

Table 9 shows the transition rates and their differences for all sample members by whether the individual owns risky assets. Transition from work to retirement increased for the whole sample as individuals aged. This increase was however, smaller for those with risky asset holdings at baseline (1998). The transition from retirement to work also 
increases for the whole sample over this period. However, we see greater increases in reentry for individuals with risky assets. These difference-in-difference estimates are not large but are consistent with the findings of the previous subsections.

To control for important demographic covariates that may affect retirement timing, we estimate a series of probits of whether an individual makes a labor force

transition. Again, the transition can be from work to retirement or retirement to work, depending on the equation, with the left hand side variable equal to 1 if the transition was made, and 0 otherwise. As the probit results in Table 10 show, this difference is not significant at any conventional level with or without covariates

In short, the results of this diff-in-diffs exercise are not conclusive. No statistically significant relationships were found between exposure to stock market risk and labor force transitions of either direction. That is somewhat surprising in light of the analysis on CPS data. More research is needed to reconcile these results.

\section{Conclusion and further research}

Using data from the Current Population Survey and the Health and Retirement Study, this report estimates consumption and labor supply responses of individuals in their 50s and 60s to the recent stock market downturn. We also test whether responses differ for individuals who are already retired by 1998.

We consistently find that individuals reduce consumption in response to adverse wealth shocks: a 1 percent drop in wealth is associated with 0.05 percent decrease in food consumption on average. The consumption response is somewhat larger for retired households that own risky assets and have experienced a negative wealth shock. These are the households whose observed changes in wealth are most likely to be exogenous 
(due to the stock market crash). As summarized in the literature review, existing studies estimate a marginal propensity to consume of 3 percent to 15 percent, suggesting that a one dollar increase in wealth leads to a 3 to 15 cent increase in consumption. Our estimate of a consumption elasticity of 5 percent can be directly compared to these MPCs if we assume a constant elasticity with respect to wealth.

We do not observe re-entry into the labor force in either the CPS or the HRS. This suggests that retirement is more or less an absorbing state, for either supply or demand reasons. Results on labor supply responses of pre-retirement samples are somewhat ambiguous. Large sample (CPS) evidence suggests a significant response among working people by delaying their retirement, although this finding is not supported strongly in the smaller HRS sample. We need further research to reconcile these findings.

Decreasing intended bequests may also be an important response to adverse wealth shocks. Very preliminary results don't show that it is important for most people in the HRS sample. Further investigation is needed to see the robustness of this finding and possible heterogeneity in the responses. 


\section{References}

Altonji, Joseph G. and Aloysius Siow (1987), “Testing the Response of Consumption to Income Changes with (Noisy) Panel data” Quarterly Journal of Economics, 102(2), 293-328.

Anderson, Kathryn H., Richard V. Burkhauser, and Joseph F. Quinn (1986), "Do Retirement Dreams Come True? The Effect of Unanticipated Events on Retirement Plans," Industrial and Labor Relations Review 39 (4): 518-526.

Banks, James, Richard Blundell, and Sarah Tanner (1998), "Is There a RetirementSavings Puzzle?" American Economics Review 88 (4): 768-788.

Dynan, Karen E. and Dean M. Maki, (2001), “Does Stock Market Wealth Matter for Consumption?” The Federal Reserve Board Finance and Economics Discussion Series, No. 21.

Haider, Steven and David Loughran, (2001), “Elderly Labor Supply: Work or Play?” Center for Retirement Research at Boston College Working Paper 2001-04

Hall, Robert E. and Frederic S. Mishkin (1982), “The Sensitivity of Consumption to Transitory Income: Estimates from Panel Data on Households,” Econometrica, 50(2), 461-481.

Hausman, Jerry A. and Lynn Paquette, (1987), “Involuntary Early Retirement and Consumption,” in Work, Health, and Income Among the Elderly, Washington D.C.: The Brookings Institution.

Hurd, Michael D. and James P. Smith, (2001), “Anticipated and Actual Bequests,” in Themes in the Economics of Aging, David Wise, ed., Chicago: The University of Chicago Press, pp. 357-389.

Hurd, Michael and James P. Smith (2002), "Expected Bequests and Their Distribution,” Unpublished Manuscript, RAND.

Juster, F. Thomas, Joseph Lupton, James P. Smith, and Frank Stafford (2001), “The Decline in Household Saving and the Wealth Effect,” RAND Working Paper.

Krueger, Alan B. and Jorn-Steffen Pischke (1992), "The Effect of Social Security on Labor Supply: A Cohort Analysis of the Notch Generation," Journal of Labor Economics 10 (4): 412-437.

Maki, Dean M. and Michael G. Palumbo (2001), "Disentangling the Wealth Effect: A Cohort Analysis of Household Saving in the 1990s." The Federal Reserve Board Finance and Economics Discussion Series, No. 23.

Mankiw, N. Gregory and Stephen P. Zeldes (1991), "The consumption of stockholders and nonstockholders," Journal of Financial Economics 29: 97-112. 
Munnell, Alicia H., Annika Sunden, and Elizabeth Lidstone (2002), "How Important are Private Pensions," An Issue in Brief; Center for Retirement Research at Boston College (8).

Poterba, James M. (2001), “The Rise of the "Equity Culture: U.S. Stockownership Patterns, 1989-1998.” MIT Unpublished Manuscript.

Sevak, Purvi (2003), "Wealth Shocks and Retirement Timing: Evidence from the Nineties," Hunter College Unpublished Manuscript.

Smith, James P. (1999), “Inheritance and Bequests,” in Wealth Work and Health: Innovations in Measurement in the Social Sciences. James P. Smith and Robert J. Willis ed. University of Michigan Press.

Stephens, Melvin Jr. (2002), "Job Loss Expectations, Realizations, and Household Consumption Behavior," Carnegie Mellon University Unpublished Manuscript.

Zeldes, Stephen P. (1989), “Consumption and Liquidity Constraints: An Empirical Investigation,” Journal of Political Economy, 97(2), 305-346. 
Table 1

Percent of Non-Pension Financial Wealth in Stocks, Retired Households in 2000

\begin{tabular}{|c|c|c|c|c|c|}
\hline Age & $\underline{\mathrm{N}}$ & $\underline{\text { Mean }}$ & $\underline{25 \text { th \%ile }}$ & Median & 75th \%ile \\
\hline $53-59$ & 264 & 0.22 & 0 & 0.10 & 0.43 \\
\hline $60-64$ & 823 & 0.24 & 0 & 0.13 & 0.45 \\
\hline $65-69$ & 1,483 & 0.22 & 0 & 0.09 & 0.41 \\
\hline $70-74$ & 1,333 & 0.22 & 0 & 0.08 & 0.41 \\
\hline$\underline{75+}$ & 3,343 & 0.19 & 0 & 0.00 & 0.34 \\
\hline
\end{tabular}

Authors' tabulations of the Health and Retirement Study.

Note: Excludes housing, pension (DB and DC accounts), and Social Security wealth. Includes stocks (direct holding and mutual funds), bonds (direct holding and mutual funds), IRAs, back accounts, CDs, real estate, autos, business, debts, and other assets. We assume that one-half of IRA or DC pension balances are invested in equity and one-half in bonds

Table 2

Percent of Non-Pension Financial Wealth in Stocks, Retired Direct Stockholders in 2000

\begin{tabular}{|c|c|c|c|c|c|}
\hline Age & $\underline{N}$ & $\underline{\text { Mean }}$ & 25th \%ile & Median & 75th \%ile \\
\hline 53-59 & 158 & 0.37 & 0.16 & 0.39 & 0.50 \\
\hline $60-64$ & 489 & 0.38 & 0.18 & 0.39 & 0.51 \\
\hline $65-69$ & 818 & 0.38 & 0.18 & 0.37 & 0.52 \\
\hline $70-74$ & 741 & 0.37 & 0.15 & 0.36 & 0.53 \\
\hline $75+$ & 1,395 & 0.42 & 0.16 & 0.39 & 0.65 \\
\hline
\end{tabular}

Authors' tabulations of the Health and Retirement Study.

Note: Excludes housing, pension (DB and DC accounts), and Social Security wealth. Includes stocks (direct holding and mutual funds), bonds (direct holding and mutual funds), IRAs, back accounts, CDs, real estate, autos, business, debts, and other assets. We assume that one-half of IRA or DC pension balances are invested in equity and one-half in bonds 
Table 3: Wealth Levels by Age in HRS

All Households ages 55-69 at Interview

\begin{tabular}{|c|c|c|c|}
\hline & 1998 & 2000 & 2002 \\
\hline & \multicolumn{3}{|c|}{ Net Worth (No DC) } \\
\hline $55-61$ & 303,650 & 386,501 & 377,562 \\
\hline $62-64$ & 316,702 & 335,595 & 364,278 \\
\hline \multirow[t]{2}{*}{$65-69$} & 339,186 & 367,993 & 347,373 \\
\hline & \multicolumn{3}{|c|}{ Net Worth (Including DC) } \\
\hline $55-61$ & 369,126 & 430,321 & 411,359 \\
\hline $62-64$ & 336,229 & 360,670 & 385,529 \\
\hline \multirow[t]{3}{*}{$65-69$} & 349,998 & 376,804 & 359,462 \\
\hline & \multicolumn{3}{|c|}{ Stocks } \\
\hline & $\underline{1998}$ & $\underline{2000}$ & 2002 \\
\hline $55-61$ & 47,940 & 69,429 & 55,992 \\
\hline $62-64$ & 65,540 & 52,236 & 42,562 \\
\hline \multirow[t]{3}{*}{$65-69$} & 50,622 & 65,510 & 46,014 \\
\hline & \multicolumn{3}{|c|}{ IRAs } \\
\hline & $\underline{1998}$ & $\underline{2000}$ & $\underline{2002}$ \\
\hline $55-61$ & 44,933 & 58,325 & 52,224 \\
\hline $62-64$ & 50,433 & 60,527 & 51,076 \\
\hline \multirow[t]{3}{*}{$65-69$} & 46,636 & 63,864 & 56,871 \\
\hline & \multicolumn{3}{|c|}{ DC Pensions } \\
\hline & $\underline{1998}$ & $\underline{2000}$ & $\underline{2002}$ \\
\hline $55-61$ & 65,069 & 43,675 & 33,797 \\
\hline $62-64$ & 19,410 & 24,991 & 21,251 \\
\hline 65-69 & 10,754 & 8,791 & 12,088 \\
\hline
\end{tabular}

* Authors tabulations of the Health and Retirement Study

Age is average age of household.

Household is retired if at least one partner is retired. 
Table 4: OLS Regression Results of Change in Log Consumption 2000 to 2002 Among All Households

\begin{tabular}{|c|c|c|c|c|c|c|}
\hline & (1) & (2) & & (3) & & Mean of Variable \\
\hline$\Delta \ln$ Net Worth & $\begin{array}{l}0.039 * * \\
(4.02)\end{array}$ & $\begin{array}{l}0.040 \\
(3.82)\end{array}$ & $* *$ & $\begin{array}{l}0.051 \\
(4.15)\end{array}$ & $* *$ & -0.005 \\
\hline$\Delta \ln C(\mathrm{t}-1)$ & & $\begin{array}{l}-0.242 \\
(-12.33)\end{array}$ & $* *$ & $\begin{array}{l}-0.253 \\
(-9.92)\end{array}$ & $* *$ & -2.813 \\
\hline$\Delta \ln$ Assets(t-1) & & $\begin{array}{l}0.014 \\
(1.43)\end{array}$ & & $\begin{array}{l}0.024 \\
(2.08)\end{array}$ & * & 0.125 \\
\hline Age 85 Survival Prob. & & & & $\begin{array}{l}0.082 \\
(2.31)\end{array}$ & * & 0.542 \\
\hline Belief about market increases & & & & $\begin{array}{c}-0.031 \\
(-0.9)\end{array}$ & & 0.462 \\
\hline Single Male Household & & & & $\begin{array}{l}0.016 \\
(0.57)\end{array}$ & & 0.116 \\
\hline Single Female Household & & & & $\begin{array}{l}-0.007 \\
(-0.34)\end{array}$ & & 0.274 \\
\hline Age & & & & $\begin{array}{c}0.002 \\
(1.5)\end{array}$ & & 65.437 \\
\hline Education & & & & $\begin{array}{l}-0.010 \\
(-2.48)\end{array}$ & * & 12.918 \\
\hline Black Race & & & & $\begin{array}{c}-0.040 \\
(-1.3)\end{array}$ & & 0.111 \\
\hline Hispanic & & & & $\begin{array}{l}0.035 \\
(0.79)\end{array}$ & & 0.046 \\
\hline Self Rated Health & & & & $\begin{array}{c}0.037 \\
(3)\end{array}$ & $* *$ & 2.606 \\
\hline Change in SRH & & & & $\begin{array}{c}-0.008 \\
(-0.38)\end{array}$ & & 2.105 \\
\hline$\Delta$ Med Ex. & & & & $\begin{array}{l}0.002 \\
(1.72)\end{array}$ & & 0.447 \\
\hline Constant & $\begin{array}{l}0.015 * \\
(1.98)\end{array}$ & $\begin{array}{l}-0.663 \\
(-11.77)\end{array}$ & $* *$ & $\begin{array}{c}-0.772 \\
(-6.17)\end{array}$ & $* *$ & \\
\hline Observations & 4,533 & 4,227 & & 3,217 & & \\
\hline Mean & 0.018 & 0.018 & & 0.018 & & \\
\hline R-squared & .01 & .01 & & .1326 & & \\
\hline
\end{tabular}

Robust $t$ statistics in parentheses

* significant at $5 \%$; ** significant at $1 \%$ 
Table 5

OLS Regression Results of Change in Log Consumption 2000 to 2002

Among Households Retired in 1998

\begin{tabular}{|c|c|c|c|c|c|c|}
\hline & (1) & (2) & & (3) & & Mean of Variable \\
\hline$\Delta \ln$ Net Worth & $\begin{array}{l}0.054 * * \\
(3.41)\end{array}$ & $\begin{array}{l}0.059 \\
(3.69)\end{array}$ & $* *$ & $\begin{array}{c}0.073 \\
(3.85)\end{array}$ & $* *$ & 0.006 \\
\hline$\Delta \ln C(\mathrm{t}-1)$ & & $\begin{array}{c}-0.266 \\
(-6.74)\end{array}$ & $* *$ & $\begin{array}{c}-0.276 \\
(-5.53)\end{array}$ & $* *$ & -2.767 \\
\hline$\Delta \ln$ Assets $(\mathrm{t}-1)$ & & $\begin{array}{l}0.028 \\
(1.61)\end{array}$ & & $\begin{array}{l}0.040 \\
(2.02)\end{array}$ & * & 0.054 \\
\hline Age 85 Survival Prob. & & & & $\begin{array}{c}0.032 \\
(0.6)\end{array}$ & & 0.535 \\
\hline Belief about market increases & & & & $\begin{array}{c}-0.060 \\
(-1.12)\end{array}$ & & 0.461 \\
\hline Single Male Household & & & & $\begin{array}{c}-0.026 \\
(-0.64)\end{array}$ & & 0.117 \\
\hline Single Female Household & & & & $\begin{array}{c}-0.016 \\
(-0.41)\end{array}$ & & 0.167 \\
\hline Age & & & & $\begin{array}{l}0.000 \\
(0.06)\end{array}$ & & 67.324 \\
\hline Education & & & & $\begin{array}{c}-0.015 \\
(-2.26)\end{array}$ & * & 12.856 \\
\hline Black Race & & & & $\begin{array}{l}-0.095 \\
(-2.06)\end{array}$ & * & 0.104 \\
\hline Hispanic & & & & $\begin{array}{c}-0.022 \\
(-0.3)\end{array}$ & & 0.036 \\
\hline Self Rated Health & & & & $\begin{array}{l}0.017 \\
(0.89)\end{array}$ & & 2.661 \\
\hline Change in SRH & & & & $\begin{array}{c}-0.006 \\
(-0.19)\end{array}$ & & 2.131 \\
\hline$\Delta$ Med Ex. & & & & $\begin{array}{l}0.001 \\
(0.84)\end{array}$ & & 0.556 \\
\hline Constant & $\begin{array}{c}0.011 \\
(1)\end{array}$ & $\begin{array}{c}-0.723 \\
(-6.49)\end{array}$ & ** & $\begin{array}{c}-0.567 \\
(-2.7)\end{array}$ & * & \\
\hline Observations & 1,925 & 1,807 & & 1,429 & & \\
\hline Mean & 0.018 & 0.018 & & 0.018 & & \\
\hline R-squared & 0.011 & 0.146 & & 0.165 & & \\
\hline
\end{tabular}

Robust $t$ statistics in parentheses

* significant at $5 \%$;* significant at $1 \%$ 
Table 6: Yearly labor force transitions in 3 periods. Fraction of all individuals who made the transition in 12 months.

\begin{tabular}{|l|c|c|c|}
\hline & $1 / 1999$ to $5 / 2000$ & $6 / 2000$ to $12 / 2001$ & $1 / 2002$ to $6 / 2003$ \\
\hline Out $\rightarrow$ in (op) & 0.0246 & 0.0279 & 0.0260 \\
In $\rightarrow$ out $(p o)$ & 0.0759 & 0.0739 & 0.0670 \\
\hline$\Delta p=$ op $-p o$ & -0.0513 & -0.0460 & -0.0410 \\
\hline
\end{tabular}

Notes: Out $\rightarrow$ in $(o p)$ is transition from out of the labor force to in the labor force. In $\rightarrow$ out $(p o)$ is transition from in labor force to out of the labor force.

Table 7: Yearly labor force transitions in 3 periods, with detailed labor force status (working, unemployed, retired, other inactive). Fraction of all individuals who made the transition in 12 months.

\begin{tabular}{|l|c|c|c|}
\hline & $\begin{array}{c}1 / 1999 \\
\text { to } 5 / 2000\end{array}$ & $\begin{array}{c}6 / 2000 \\
\text { to } 12 / 2001\end{array}$ & $\begin{array}{c}1 / 2002 \\
\text { to } 6 / 2003\end{array}$ \\
\hline Retired $\rightarrow$ Working $(r w)$ & $\mathbf{. 0 1 0 8}$ & $\mathbf{. 0 1 2 1}$ & $\mathbf{. 0 1 0 6}$ \\
Inactive $\rightarrow$ Working $(i w)$ & .0112 & .0128 & .0119 \\
Retired $\rightarrow$ Unemployed $(r u)$ & $\mathbf{. 0 0 1 2}$ & $\mathbf{. 0 0 1 1}$ & $\mathbf{. 0 0 1 6}$ \\
Inactive $\rightarrow$ Unemployed $(i u)$ & .0014 & .0019 & .0018 \\
\hline$o p=r w+i w+r u+i u$ & .0246 & .0279 & .0260 \\
\hline Working $\rightarrow$ Retired $(w r)$ & $\mathbf{. 0 4 5 0}$ & $\mathbf{. 0 4 2 7}$ & $\mathbf{. 0 3 7 0}$ \\
Working $\rightarrow$ Inactive $(w i)$ & .0246 & .0247 & .0236 \\
Unemployed $\rightarrow$ Retired $(u r)$ & $\mathbf{. 0 0 2 9}$ & $\mathbf{. 0 0 2 8}$ & $\mathbf{. 0 0 2 8}$ \\
Unemployed $\rightarrow$ Inactive $(u i)$ & .0034 & .0038 & .0035 \\
\hline$p o=w r+w i+u r+u i$ & .0759 & .0739 & .0670 \\
\hline$\Delta p=o p-p o$ & -.0513 & -.0460 & -.0410 \\
\hline
\end{tabular}


Table 8: Logit Estimates of "Not in Labor Force" Individuals Ages 50-75, March CPS 1988-2002

\begin{tabular}{|c|c|c|c|c|c|c|c|c|}
\hline & \multicolumn{4}{|c|}{ Men } & \multicolumn{4}{|c|}{ Women } \\
\hline & $\frac{\text { Marginal }}{\underline{\text { Effect }}}$ & $\underline{\text { Coefficient }}$ & $\underline{\mathrm{SE}}$ & & $\frac{\text { Marginal }}{\underline{\text { Effect }}}$ & $\underline{\text { Coefficient }}$ & $\underline{\mathrm{SE}}$ & \\
\hline Ages 55-59 & 0.09 & 0.59 & 0.02 & $* *$ & 0.10 & 0.54 & 0.02 & $* *$ \\
\hline Ages $60-63$ & 0.23 & 1.49 & 0.02 & $* *$ & 0.22 & 1.22 & 0.02 & $* *$ \\
\hline Ages 64-66 & 0.36 & 2.30 & 0.02 & $* *$ & 0.35 & 1.99 & 0.02 & $* *$ \\
\hline Ages 67-70 & 0.45 & 2.84 & 0.03 & $* *$ & 0.46 & 2.59 & 0.02 & $* *$ \\
\hline Ages 71-75 & 0.52 & 3.34 & 0.03 & $* *$ & 0.59 & 3.33 & 0.03 & $* *$ \\
\hline 1989 & 0.00 & 0.00 & 0.04 & & -0.02 & -0.11 & 0.03 & $* *$ \\
\hline 1990 & -0.01 & -0.06 & 0.03 & $*$ & -0.02 & -0.10 & 0.03 & $* *$ \\
\hline 1991 & -0.01 & -0.05 & 0.03 & & -0.02 & -0.12 & 0.03 & ** \\
\hline 1992 & -0.02 & -0.12 & 0.04 & $* *$ & -0.03 & -0.17 & 0.03 & $* *$ \\
\hline 1993 & -0.01 & -0.05 & 0.04 & & -0.03 & -0.18 & 0.03 & $* *$ \\
\hline 1995 & 0.00 & 0.00 & 0.04 & & -0.05 & -0.26 & 0.03 & $* *$ \\
\hline 1996 & 0.00 & -0.01 & 0.04 & & -0.05 & -0.26 & 0.03 & $* *$ \\
\hline 1997 & -0.09 & -0.56 & 0.04 & $* *$ & -0.02 & -0.14 & 0.03 & $* *$ \\
\hline 1998 & -0.01 & -0.07 & 0.04 & $*$ & -0.06 & -0.36 & 0.03 & $* *$ \\
\hline 1999 & -0.01 & -0.05 & 0.04 & & -0.06 & -0.35 & 0.03 & $* *$ \\
\hline 2000 & -0.01 & -0.05 & 0.04 & & -0.07 & -0.41 & 0.03 & $* *$ \\
\hline 2001 & -0.02 & -0.12 & 0.04 & $* *$ & -0.07 & -0.42 & 0.03 & $* *$ \\
\hline 2002 & -0.02 & -0.12 & 0.04 & $* *$ & -0.08 & -0.44 & 0.03 & $* *$ \\
\hline Stockowner & -0.09 & -0.57 & 0.05 & $* *$ & -0.04 & -0.20 & 0.05 & ** \\
\hline Stockowner*1989 & -0.02 & -0.15 & 0.08 & $* *$ & 0.00 & 0.01 & 0.07 & \\
\hline Stockowner*1990 & -0.01 & -0.03 & 0.08 & & -0.03 & -0.19 & 0.07 & ** \\
\hline Stockowner*1991 & -0.01 & -0.06 & 0.08 & & -0.03 & -0.19 & 0.07 & ** \\
\hline Stockowner*1992 & 0.00 & 0.03 & 0.08 & & -0.03 & -0.14 & 0.07 & $* *$ \\
\hline Stockowner*1993 & 0.00 & 0.01 & 0.08 & & -0.03 & -0.17 & 0.07 & $* *$ \\
\hline Stockowner*1995 & -0.04 & -0.27 & 0.08 & $* *$ & -0.04 & -0.24 & 0.07 & ** \\
\hline Stockowner*1996 & -0.06 & -0.38 & 0.08 & $* *$ & -0.06 & -0.34 & 0.07 & $* *$ \\
\hline Stockowner*1997 & -0.06 & -0.41 & 0.08 & $* *$ & -0.05 & -0.28 & 0.07 & $* *$ \\
\hline Stockowner*1998 & -0.04 & -0.28 & 0.08 & $* *$ & -0.05 & -0.30 & 0.07 & ** \\
\hline Stockowner*1999 & -0.06 & -0.36 & 0.08 & $* *$ & -0.07 & -0.39 & 0.07 & $* *$ \\
\hline Stockowner*2000 & -0.07 & -0.47 & 0.08 & $* *$ & -0.07 & -0.37 & 0.07 & ** \\
\hline Stockowner*2001 & -0.04 & -0.28 & 0.08 & $* *$ & -0.06 & -0.32 & 0.07 & $* *$ \\
\hline Stockowner*2002 & -0.06 & -0.40 & 0.08 & $* *$ & -0.06 & -0.36 & 0.07 & ** \\
\hline Married & -0.10 & -0.66 & 0.02 & $* *$ & 0.06 & 0.33 & 0.01 & ** \\
\hline Has Children & -0.03 & -0.20 & 0.03 & $* *$ & 0.05 & 0.31 & 0.02 & $* *$ \\
\hline \$ of Unearned Income & 0.000004 & 0.000027 & 0.000001 & $* *$ & 0.000003 & 0.000017 & 0.000001 & $* *$ \\
\hline Constant & & -1.43 & 0.03 & $* *$ & & -0.98 & 0.03 & $* *$ \\
\hline Mean NILF & 0.42 & & & & 0.59 & & & \\
\hline R-Sq. & 0.29 & & & & 0.21 & & & \\
\hline
\end{tabular}

Notes: ** denotes statistical significance at the 5\% level, * denotes statistical significance at the $10 \%$ level.

Equations are estimated on pooled cross sections of the March CPS and use sample weights.

1988 is the excluded group in the estimation and 1994 is excluded from the analysis because of inconsistencies in labor force measures in the 1994 CPS. 
Table 9: Labor force transitions in HRS

(Individuals ages 52-72 at $\mathrm{t}_{1}$ interview)

Transition from work to retirement

\begin{tabular}{lccc}
\hline \multirow{2}{*}{ Period } & \multicolumn{3}{c}{ Owns Risky assets in 1998? } \\
1998-2000 & 0.059 & 0.097 & Total \\
\cline { 2 - 4 } 2000-2002 & 0.069 & 0.100 & 0.083 \\
Difference & 0.010 & 0.003 \\
\cline { 2 - 4 } & \multicolumn{3}{c}{0.089} \\
\hline \multicolumn{4}{c}{ Transition from retirement to work } \\
Period & \multicolumn{3}{c}{ Owns Risky assets in 1998? } \\
1998-2000 & 0.019 & 0.020 & Yes \\
2000-2002 & 0.026 & 0.030 & 0.020 \\
Difference & 0.007 & 0.010 & 0.028 \\
\cline { 2 - 4 }
\end{tabular}


Table 10: Labor force transitions in HRS. Probit estimates

\begin{tabular}{|c|c|c|c|c|}
\hline & $\begin{array}{l}\text { Work } \rightarrow \\
\text { Retirement }\end{array}$ & $\begin{array}{l}\text { Work } \rightarrow \\
\text { Retirement }\end{array}$ & $\begin{array}{l}\text { Retirement } \rightarrow \\
\text { Work }\end{array}$ & $\begin{array}{l}\text { Retirement } \rightarrow \\
\text { Work }\end{array}$ \\
\hline period & $\begin{array}{l}0.081 \\
(1.50)\end{array}$ & $\begin{array}{l}0.068 \\
(1.23)\end{array}$ & $\begin{array}{l}0.122 \\
(1.64)\end{array}$ & $\begin{array}{l}0.074 \\
(0.98)\end{array}$ \\
\hline $\begin{array}{l}\text { Risky assets in } \\
1998(0-1)\end{array}$ & $\begin{array}{l}0.262 \\
(5.86)^{* *}\end{array}$ & $\begin{array}{l}0.262 \\
(5.49)^{* *}\end{array}$ & $\begin{array}{l}0.021 \\
(0.31)\end{array}$ & $\begin{array}{l}0.003 \\
(0.03)\end{array}$ \\
\hline $\begin{array}{l}\text { Risky assets } x \\
\text { period }\end{array}$ & $\begin{array}{l}-0.062 \\
(0.94)\end{array}$ & $\begin{array}{l}-0.065 \\
(0.98)\end{array}$ & $\begin{array}{l}0.045 \\
(0.49)\end{array}$ & $\begin{array}{l}0.059 \\
(0.63)\end{array}$ \\
\hline Age & & $\begin{array}{l}0.012 \\
(3.51)^{* *}\end{array}$ & & $\begin{array}{l}0.028 \\
(4.94)^{* *}\end{array}$ \\
\hline Female & & $\begin{array}{l}-0.226 \\
(8.25)^{* *}\end{array}$ & & $\begin{array}{l}-0.224 \\
(5.01)^{* *}\end{array}$ \\
\hline Years of ed. & & $\begin{array}{l}0.016 \\
(3.13)^{* *}\end{array}$ & & $\begin{array}{l}0.016 \\
(2.13)^{*}\end{array}$ \\
\hline Black & & $\begin{array}{l}0.048 \\
(1.11)\end{array}$ & & $\begin{array}{l}0.062 \\
(0.96)\end{array}$ \\
\hline Hispanic & & $\begin{array}{l}0.105 \\
(1.88)\end{array}$ & & $\begin{array}{l}0.055 \\
(0.62)\end{array}$ \\
\hline Family size & & $\begin{array}{l}-0.083 \\
(2.48)^{*}\end{array}$ & & $\begin{array}{l}-0.019 \\
(0.35)\end{array}$ \\
\hline Spouse retired & & $\begin{array}{l}-0.045 \\
(1.10)\end{array}$ & & $\begin{array}{l}-0.003 \\
(0.04)\end{array}$ \\
\hline Constant & $\begin{array}{l}-1.562 \\
(42.01)^{* *}\end{array}$ & $\begin{array}{l}-2.239 \\
(9.46)^{* *}\end{array}$ & $\begin{array}{l}-2.072 \\
(38.33)^{* *}\end{array}$ & $\begin{array}{l}-3.876 \\
(9.68)^{* *}\end{array}$ \\
\hline Observations & 15,497 & 15,457 & 15,497 & 15,457 \\
\hline
\end{tabular}

Robust z statistics in parentheses

* significant at 5\%; ** significant at $1 \%$ 
Figure 1

Standard and Poor's 500 Index, Year End Levels

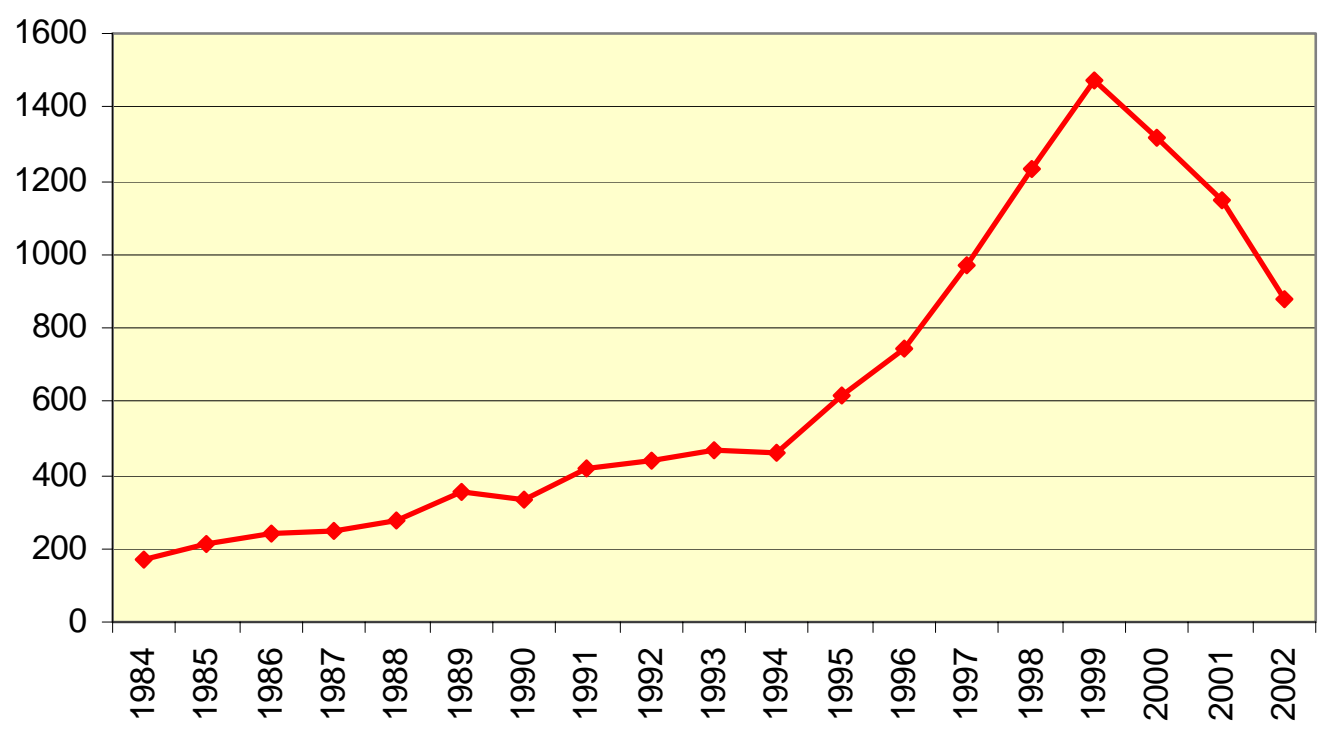

Figure 2

Projected Losses in Stock Market, as a Share of Non-Pension Financial Wealth Retired Households Who Hold Stocks Directly

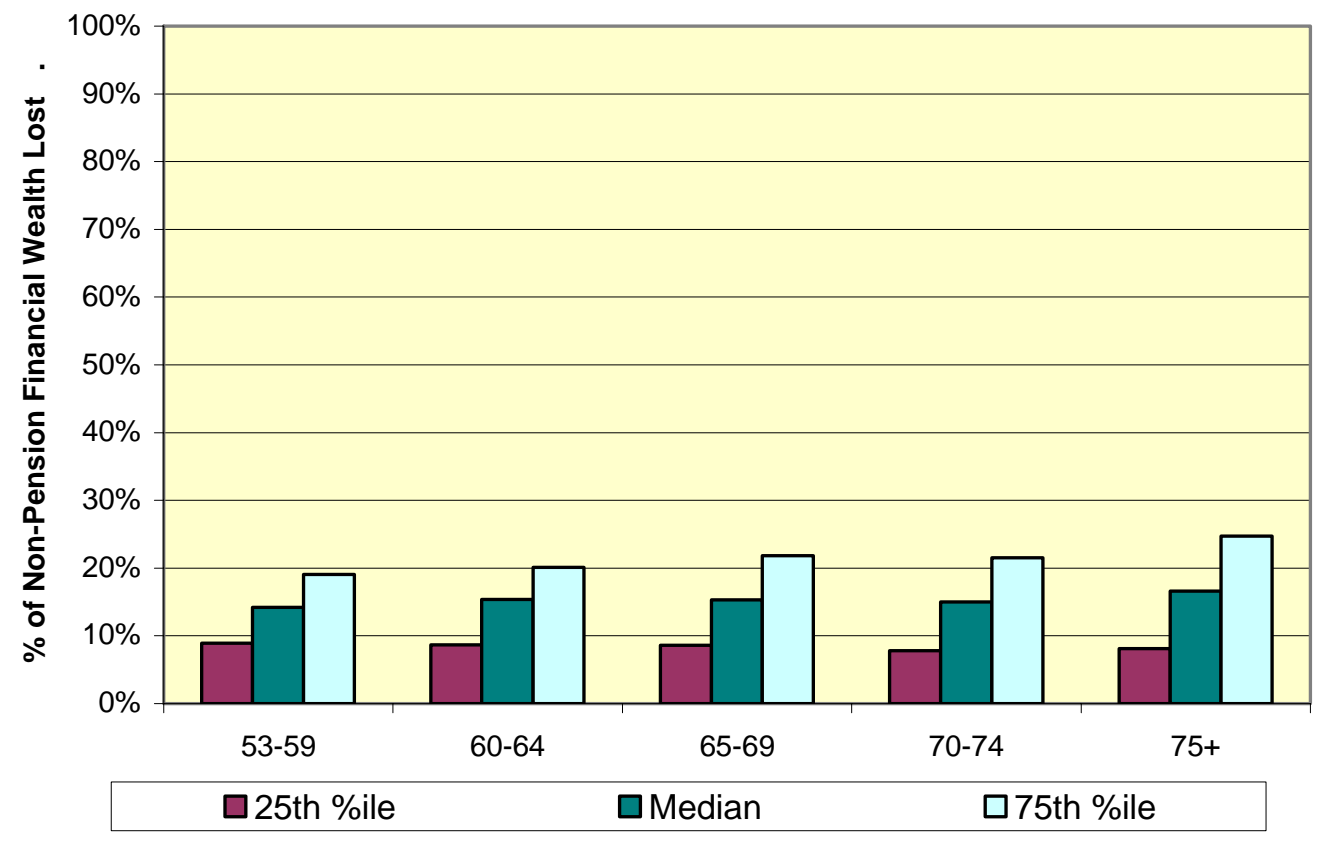


Figure 3: Wealth Levels

Households Ages 55-69

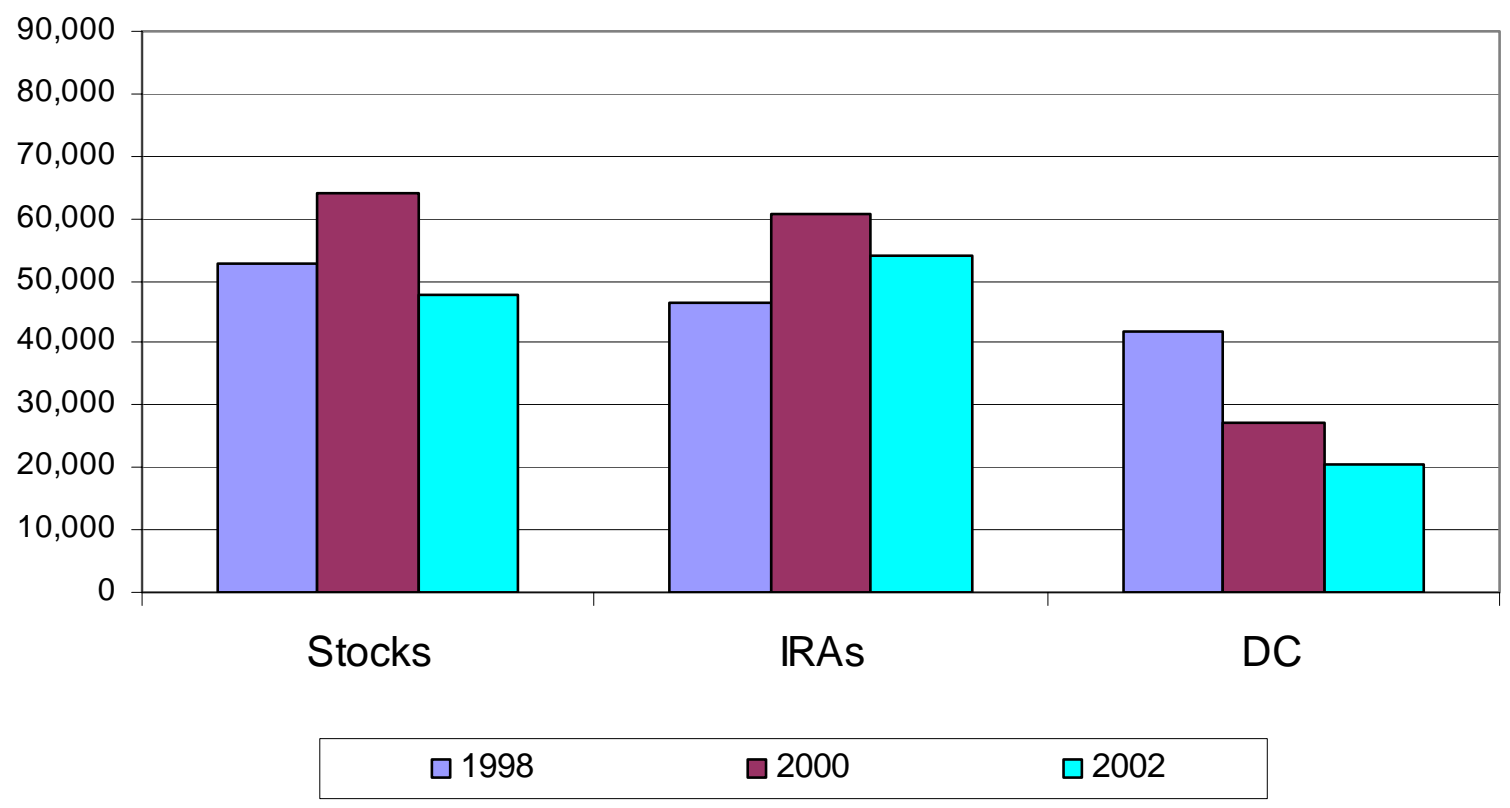

Figure 4: Wealth Levels

Households Retired in 1998, Ages 55-69

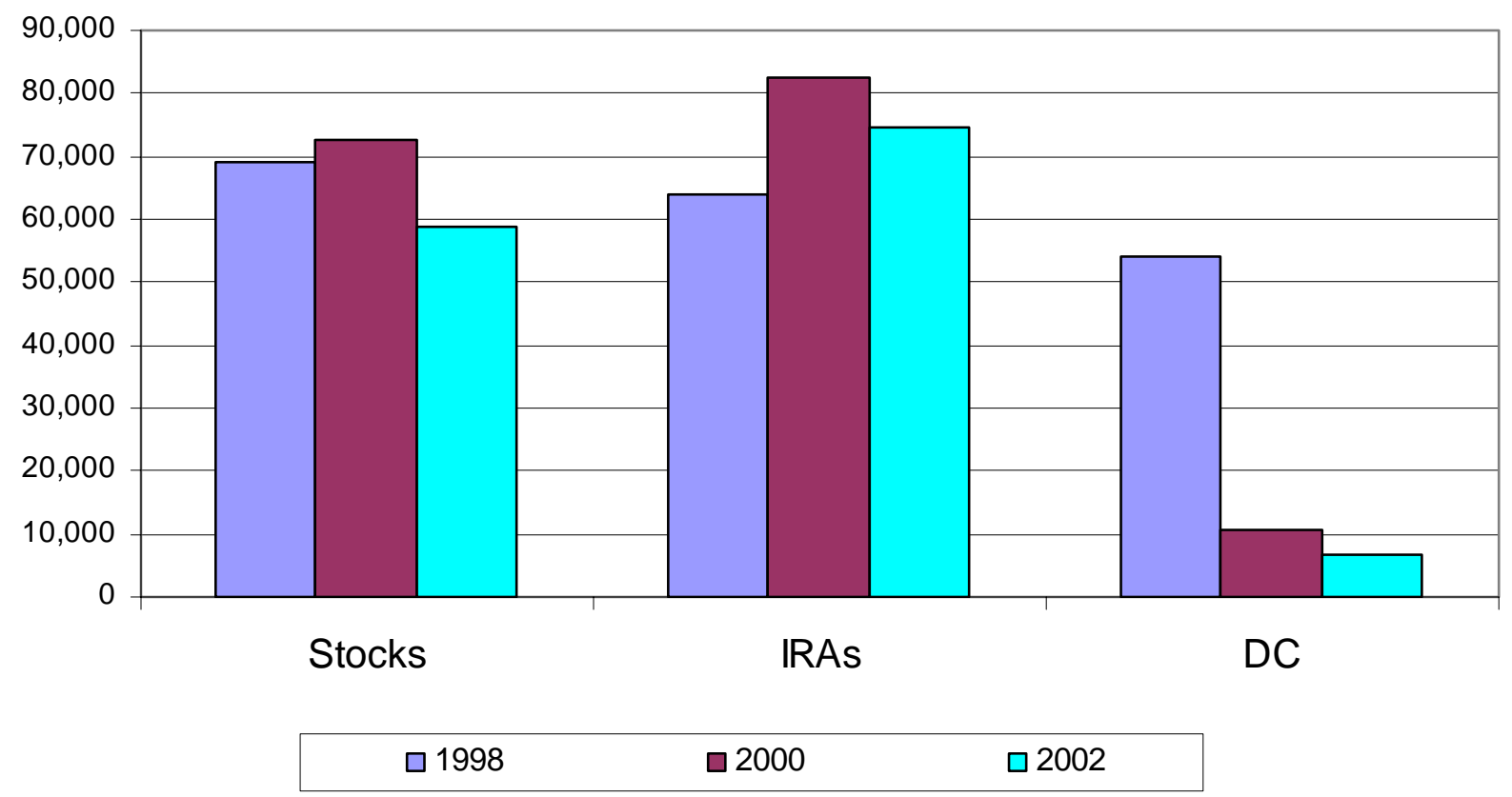


Figure 5: Log changese in consumtpion and log changes in wealth. Nonparamteric (lowess) regression. All households

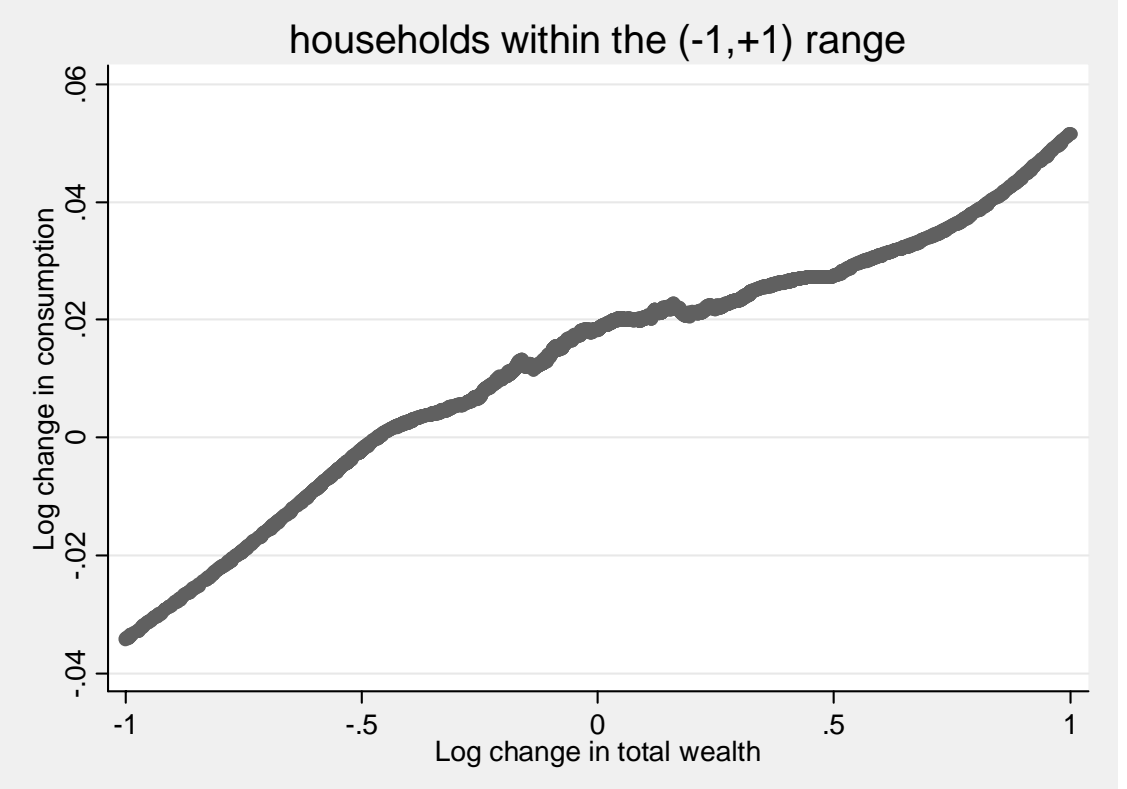

Note: We constrain this estimation to changes in log wealth between +1 and -1 . Since the estimates are locally weighted regressions, the results in the relevant range are the same regardless of inclusion or exclusion of the rest.

Figure 6: Log changes in consumption and log changes in wealth. Nonparametric (lowess) regression. Households with risky assets in 1998.

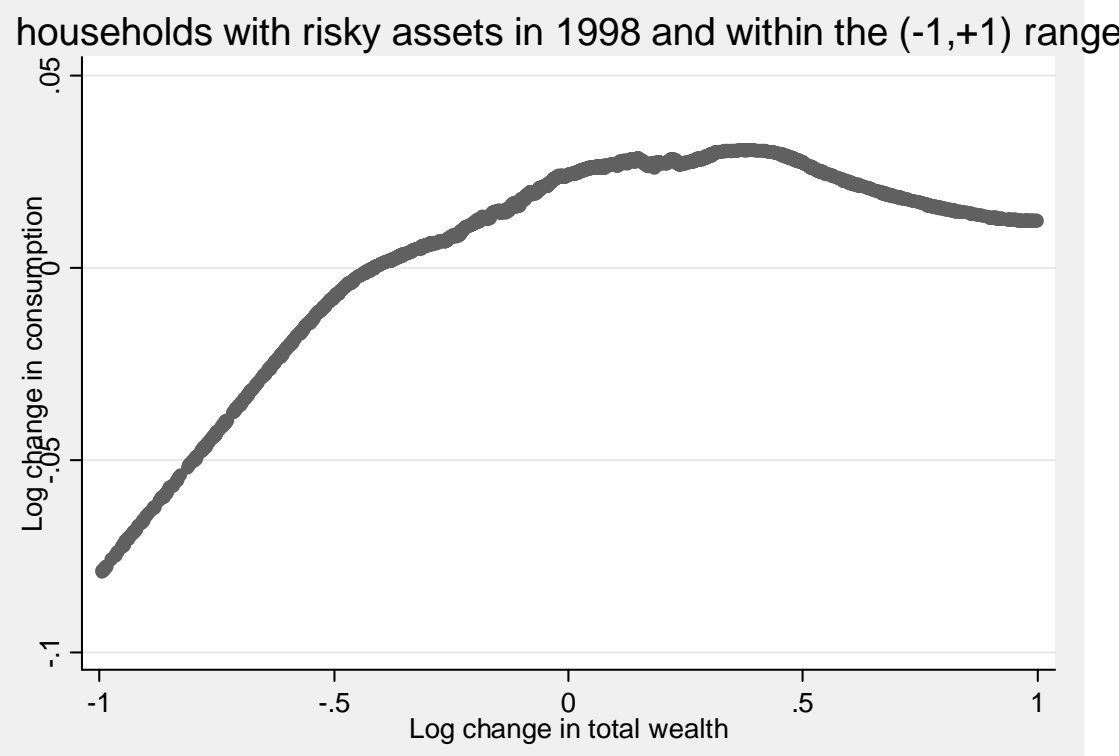




\section{Figure 7}

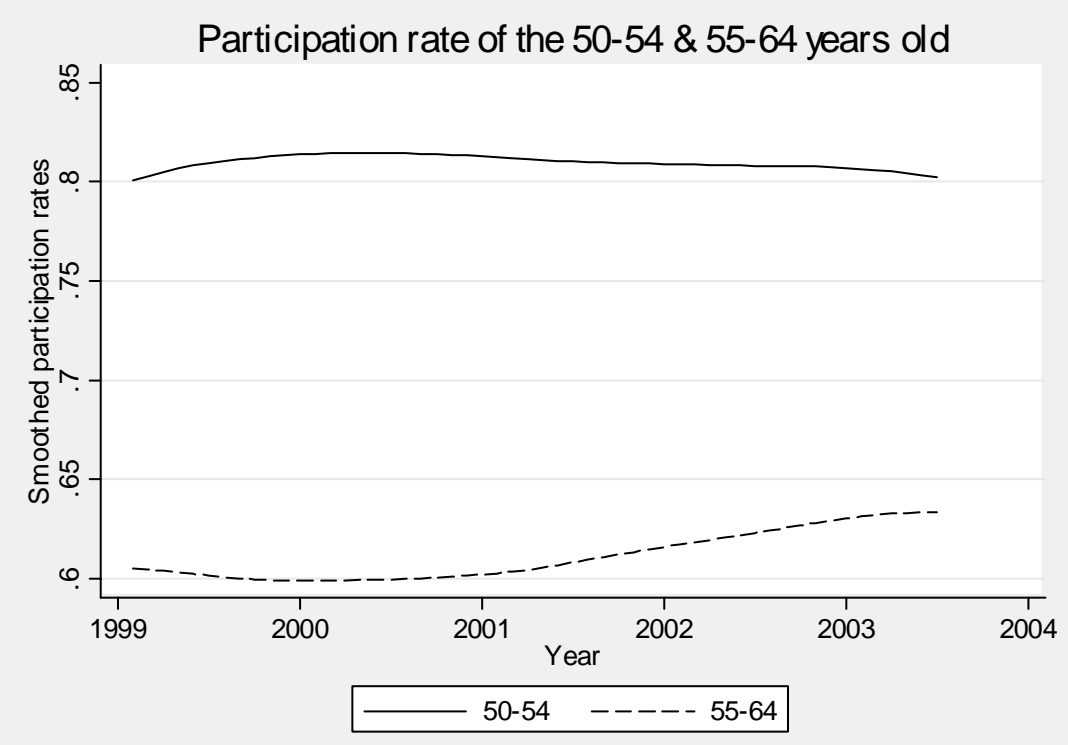

Authors tabulations of monthly CPS data.

\section{Figure 8}

Year-to-year change in participation rate, 55-64 years old

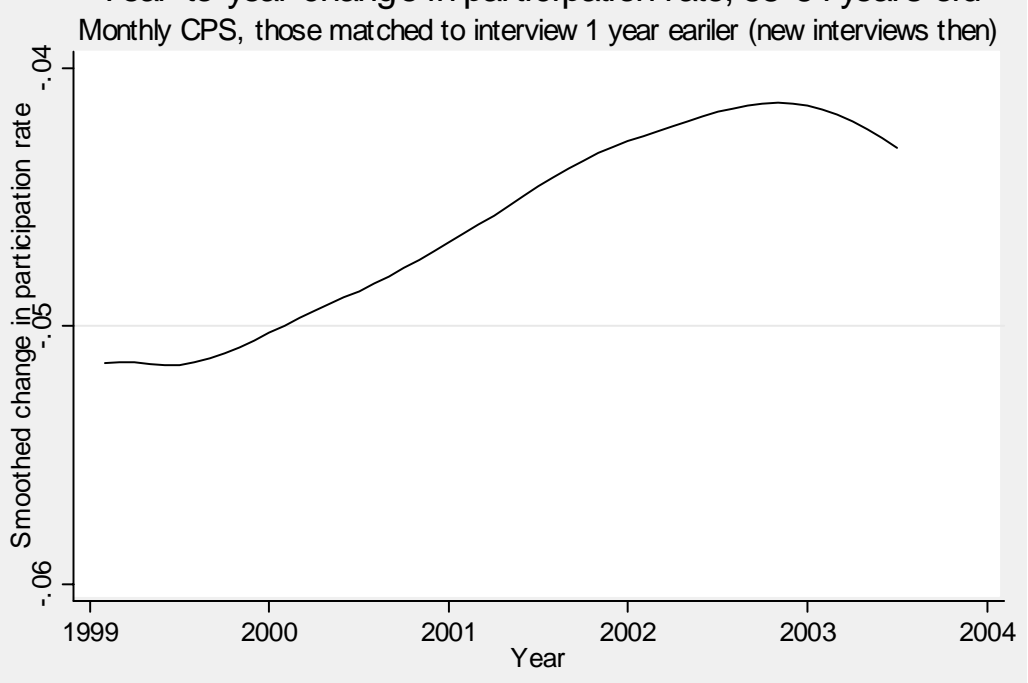

Authors tabulations of monthly CPS data. 